IZA DP No. 8354

New Evidence on the Relationship between Risk Attitudes and Self-Employment

Olga J. Skriabikova

Thomas Dohmen

Ben Kriechel

July 2014 


\title{
New Evidence on the Relationship between Risk Attitudes and Self-Employment
}

\author{
Olga J. Skriabikova \\ ROA, Maastricht University
}

Thomas Dohmen

University of Bonn,

ROA, Maastricht University and IZA

\section{Ben Kriechel}

Economix Research \& Consulting, ROA, Maastricht University and IZA

\author{
Discussion Paper No. 8354 \\ July 2014
}

IZA
P.O. Box 7240
53072 Bonn
Germany

Phone: +49-228-3894-0

Fax: +49-228-3894-180

E-mail: iza@iza.org

\begin{abstract}
Any opinions expressed here are those of the author(s) and not those of IZA. Research published in this series may include views on policy, but the institute itself takes no institutional policy positions. The IZA research network is committed to the IZA Guiding Principles of Research Integrity.

The Institute for the Study of Labor (IZA) in Bonn is a local and virtual international research center and a place of communication between science, politics and business. IZA is an independent nonprofit organization supported by Deutsche Post Foundation. The center is associated with the University of Bonn and offers a stimulating research environment through its international network, workshops and conferences, data service, project support, research visits and doctoral program. IZA engages in (i) original and internationally competitive research in all fields of labor economics, (ii) development of policy concepts, and (iii) dissemination of research results and concepts to the interested public.
\end{abstract}

IZA Discussion Papers often represent preliminary work and are circulated to encourage discussion. Citation of such a paper should account for its provisional character. A revised version may be available directly from the author. 
IZA Discussion Paper No. 8354

July 2014

\section{ABSTRACT}

\section{New Evidence on the Relationship between Risk Attitudes and Self-Employment}

This paper analyses the impact of risk attitudes on the decision to become self-employed among individuals who grew up under the communist regime in Ukraine, which banned selfemployment so that individuals could not observe what it is like to be self-employed. Since the intra-family transmission of self-employment experiences was largely shut down, the observed correlation between risk preferences and self-employment after transition is unlikely to be driven by parents transmitting self-employment experience and risk preferences to their children. Robustness checks on a sample of East Germans confirm that such a third factor explanation is implausible, thus shedding light on the causal nature of the relation between risk preferences and the decision to become self-employed.

JEL Classification: J24, D81, P3

Keywords: self-employment, risk attitudes, intergenerational transmission of self-employment and risk attitudes, SOEP, ULMS

Corresponding author:

Olga J. Skriabikova

Maastricht University

Research Centre for Education and the Labour Market

P.O. Box 616

6200 MD Maastricht

The Netherlands

E-mail: olga.skriabikova@gmail.com 


\section{INTRODUCTION}

Self-employment is an important driver of economic activity. Not surprisingly, the determinants of self-employment have been on the economic research agenda for a long time, and several factors have been identified. ${ }^{1}$ Already in 1755 , Cantillon recognised that entrepreneurial activities are risky. He argues that the self-employed faces a more variable stream of earnings because of uncertain product demand, which results in revenue fluctuations and can lead to business failure. $^{2}$

Given the risky nature of self-employment, heterogeneity in risk preferences across individuals should affect the choice of employment status (see also Kihlstrom and Laffont, 1979). ${ }^{3}$ A host of empirical studies have established a robust positive correlation between individual willingness to take risks and the probability of being self-employed (e.g. Cramer et al., 2002 Ekelund et al., 2005; Fossen, 2011). Skeptics might raise the concern that self-employment experience makes individuals more willing to take risks. In order to preclude that such exposure effects drive the relation between risk preference and self-employment status, Caliendo et al. (2009) show that risk attitudes measured in the 2004 wave of the German Socio-Economic Panel Study (SOEP) predict the respondents' transition into self-employment in 2005. Similarly, Brown et al. (2011) document that risk attitudes measured in the 1996 wave of the Panel Study of Income Dynamics (PSID) predict the respondents' decision to become self-employed up to nine years later, suggesting a causal effect of risk attitude on the probability of entering

\footnotetext{
${ }^{1} \mathrm{~A}$ non-exhaustive list of micro-level self-employment determinants includes financial aspects, i.e. liquidity constraints, access to credit markets, wealth (Evans and Jovanovic, 1989 , Lindh and Ohlsson, 1996, Hundley 2006); human capital, i.e. formal education, skills, labour market experience (Rees and Shah 1986 Evans and Leighton, 1989, Lazear, 2004, 2005); entrepreneurial ability (Hartog and van Praag, 2010); social capital and networks (Gomez and Santor, 2001); risk attitude (van Praag and Cramer | 2001|| Ekelund et al., 2005) and personality traits (Evans and Leighton, 1989, Schiller and Crewson, 1997, Burke et al., 2002).

${ }^{2}$ Empirical studies on earnings distributions consistently show that self-employed earnings are more variable than wages. See, for example, Falter (2007b), Rosen and Willen (2002); Parker (1999) and references therein.

${ }^{3}$ The role of the entrepreneur as a risk-bearer has been discussed already in early theoretical work, e.g. Knight, 1921, Schumpeter, 1934, 1939).
} 
self-employment. But the authors caution the reader that an unobserved third factor that influences both the decision to become self-employed and risk attitude might drive their result.

A plausible third factor is the influence of parents who shape their children's risk attitudes through intergenerational preference transmission (Dohmen et al. 2012) and potentially affect children's decision to become self-employed indirectly or directly. The most obvious direct channel is the transfer of businesses from parents to children. ${ }^{4}$ But there are also indirect channels such as the transmission of information and beliefs about self-employment through which children of self-employed parents might grow more likely to become self-employed themselves (Hout and Rosen, 2000; Falter, 2007a; Andersson and Hammarstedt, 2010). For example, growing up with self-employed parents can provide children with invaluable information on what it is like to be self-employed.

In this paper, we analyse a setting in which the scope for this kind of third factor explanation is limited or even non-existent. We provide new evidence that supports a causal interpretation of the correlation between risk attitudes and the probability of becoming self-employed. We exploit the fact that self-employment was banned for at least 45 years in Ukraine, so that the cohorts whose self-employment decision after transition that we study grew up without exposure to self-employment. A very substantial fraction of these individuals has parents who never had the right to become self-employed during their active labour market career. ${ }^{5}$

We describe our research strategy in the next section and describe the data we use in section 3. In section 4, we report the findings from our empirical analysis, and end with a conclusion.

\footnotetext{
${ }^{4}$ Fairlie and Robb (2007) report that $8.2 \%$ of current business owners inherited their business or received it as a gift. Based on the exact match between occupation-sector combination of fathers and sons, Dunn and HoltzEakin (2000) report that $36 \%$ of second generation self-employed sons are occupational followers as compared to $8 \%$ of those who never become self-employed. Praag and Ophem (1995) analyse the determinants and modes of becoming an entrepreneur in the Netherlands and report that $9.5 \%$ of entrepreneurs in their sample entered into self-employment by taking over a family firm.

${ }^{5}$ This is clearly true for individuals whose parents were born after 1930 in West Ukraine and after 1915 in the Eastern part of Ukraine, i.e. whose parents were 15 years of age when self-employment was banned.
} 
We start by illustrating the relation between family background, risk attitudes and selfemployment in Figure 1.

FigURE 1. Schematic relationship between risk attitude, self-employment, and family

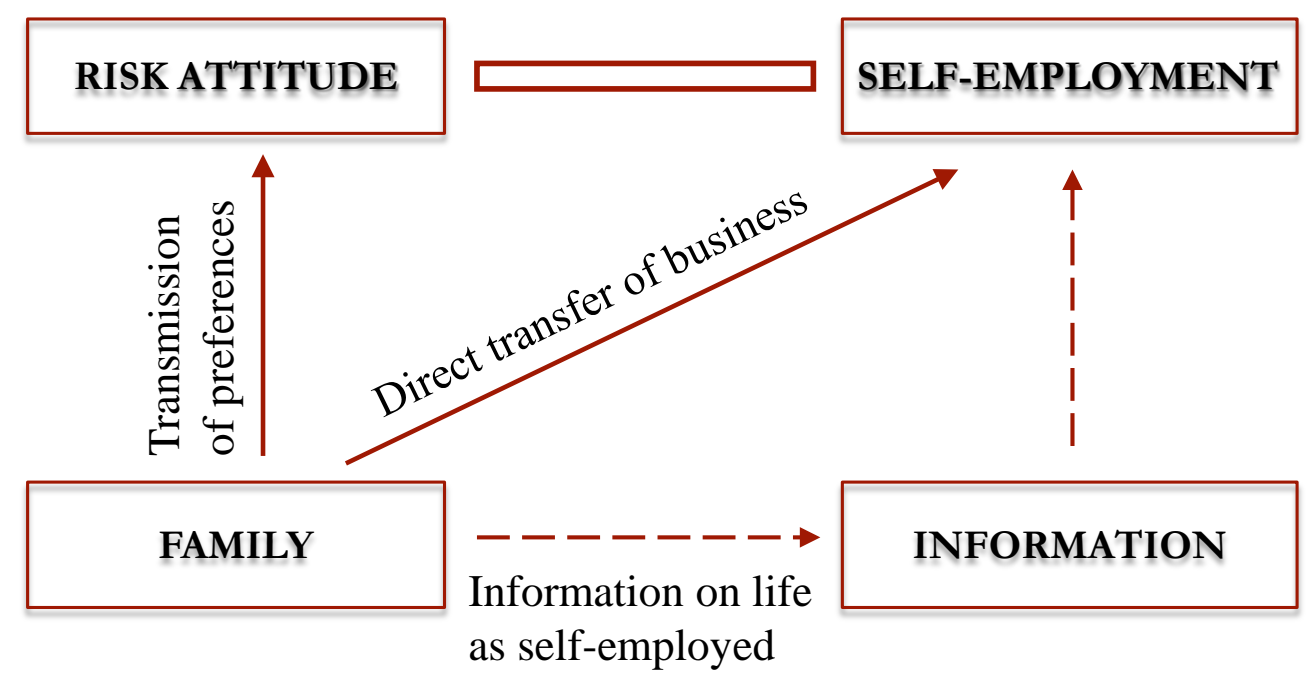

Family background can potentially impact the decision to become self-employed via direct and indirect channels. The most obvious direct channel is the transfer of a family business to children. Indirect channels might include the provision of financial means or access to networks, but also the transmission of information about what it is like to be self-employed. Children who observe their self-employed parents might become more willing to become self-employed themselves. If these indirect and direct channels are at work, we should observe a positive relation between parents' and children's probability of being self-employed. Such a relation is confirmed empirically. ${ }^{6}$

\footnotetext{
${ }^{6}$ See, e.g., Praag and Ophem (1995).
} 
The literature has also shown that risk attitudes are transmitted from one generation to the next (Dohmen et al., 2012). Suppose that the self-employed were on average more willing to take risks than the non-self-employed. Even if there was no causal effect of risk attitudes on the decision to become self-employed, we would observe a positive correlation between the risk attitudes of labour market entrants and their later self-employment decision when the simultaneous impact of parents on self-employment propensity and risk attitudes is neglected. This is because children of the self-employed would be more likely to become self-employed and are at the same time more willing to take risks, due to their family background. In fact, we observe that children of self-employed fathers are on average significantly more willing to take risks ( 0.32 points on the 11-point risk scale, two tailed t-test, $\mathrm{p}$-value $<0.001)$ than children whose fathers opted for regular employment, in a sample of 15-year old respondents to the German Socio-Economic Panel Study (SOEP) whose parents' self-employment decision was not constrained by law. In light of this evidence, the relation between risk attitudes and selfemployment might not necessarily be causal even if it is identified by using a measure of risk attitudes prior to actually becoming self-employed, because both these measured risk attitudes and the propensity to become self-employed were influenced by parents. ${ }^{7}$ It is therefore still an open question, whether an arrow should point from risk attitudes to self-employment or not.

Our strategy is to shed light on the nature of the relation between risk attitudes and selfemployment by shutting down the channel of transmission of information about what it is like to be self-employed and precluding that parents can transfer their business to their children. To this end we focus on a sample of Ukrainians whose parents could not become self-employed due to legal restrictions. In Soviet Ukraine, an extremely restrictive institutional regulation with

\footnotetext{
${ }^{7}$ Using risk attitudes of the father as an instrument, we find a significant positive effect of own (instrumented) risk attitudes on the probability of being self-employed in the West German sample of the SOEP. This estimation suggests a causal interpretation of the role of willingness to take risk for the probability of becoming self-employed since it is unlikely that risk attitude of fathers were influenced by self-employment experience of their children. However, the instrument is likely to be invalid because of the third factor such as father's self-employment experience.
} 
respect to free trade and entrepreneurial activities was in force from the late 1920's onwards in the East and from the end of World War II in the West until the end of the 1980's. Any private for-profit activity was illegal until 1985, when the 'Perestroika' initiatives heralded a period of reforms. The number of self-employed individuals started growing in the 1990's, after the official separation of Ukrainian SSR (Soviet Socialist Republic) from the collapsing Soviet empire in 1991. Before that, commercial activities conducted not by the state and not for the state were considered a criminal offence (for example, Gelfand, 1964; Trofimov, 1975 Andruhin, 2011).

We show that the correlation between risk attitudes and self-employment for Ukrainians observed in 2007 is strong and significant. As this correlation cannot be driven by the simultaneous parental transmission of risk attitudes and information about what it is like to be self-employed, we can rule out this third factor explanation that might undermine a causal interpretation of the studies by Caliendo et al. (2009) and Brown et al. (2011), who show that currently measured risk attitudes predict future self-employment decisions.

\section{Data AND VARiables}

For our main empirical analysis, we use data from the Ukrainian Longitudinal Monitoring Survey (ULMS). For a robustness check, we exploit data from the East German sub-sample of the German Socio-Economic Panel (SOEP). Next to general demographic and socio-economic characteristics, both data sets contain a direct measure of risk attitude and information on parental education and occupation. The ULMS panel consists of three waves, which were collected in 2003,2004 , and $2007 .{ }^{8}$ The analysis in this paper is based on the last wave, as only in 2007 information on risk attitudes was collected. We restrict our sample to individuals between 18 and 65 years of age and discard individuals who are not participating in the labour market,

\footnotetext{
${ }^{8}$ For a detailed overview of the ULMS, see Lehmann et al. (2012). A fourth wave of this data will soon become available.
} 
army personnel or farmers, those receiving pension or being involved in full-time education, as well as individuals who are helping a self-employed family member.

The self-employment status variable is equal to one if in 2007 the answer to the question about current status on the labour market is either self-employed, entrepreneur or employer. The reference category corresponds to individuals who are in paid employment. Risk attitude is measured by a subjective self-assessment of willingness to take risks in general on a scale from zero to ten, on which higher values reflect greater willingness to take risks. The question was taken from the SOEP and translated into Ukrainian and Russian. ${ }^{9}$ The exact wording of the question translated into English is: "How do you see yourself: are you generally a person who is fully prepared to take risks or do you try to avoid taking risks? Please tick a box on the scale, where the value 0 means: 'not at all willing to take risks' and the value 10 means: 'very willing to take risks'." 10 Dohmen et al. (2011) have shown that this question is significantly related to paid lottery choices, and that it explains behaviour in a range of important real life decision domains. Descriptive statistics with mean and standard deviation of the main variables are shown in Table 1 ,

Easy access to information on self-employment, access to wealth and to social networks all enhance business opportunities and can potentially reduce the perceived uncertainty associated with self-employment. We use information on occupational status and educational achievement of both parents to control for access to information and networks. ${ }^{11}$ The egalitarian policy of the Soviet Union assured that there was little income inequality, and therefore, the distribution of wealth across households was quite homogeneous in the beginning of transition. ${ }^{12}$ However,

\footnotetext{
${ }^{9}$ Respondents could chose whether the interview was conducted in Russian or Ukrainian, the two main languages spoken in Ukraine.

${ }^{10}$ See Dohmen et al. (2011) for the exact wording of the question in German.

${ }^{11}$ More educated individuals would be more likely to have been former members of the official ruling Communist party and they could have retained some personal access to politically and economically important networks.

${ }^{12}$ According to the official Gini coefficient measure, income inequality did not increase dramatically during the transition years. The Gini coefficient remained at about 28-30 in 2003-2007.
} 
TABLE 1. Descriptive statistics

\begin{tabular}{lccccc}
\hline & \multicolumn{3}{c}{ ULMS } & \multicolumn{3}{c}{ SOEP $^{1}$} \\
\cline { 2 - 6 } Variable & Mean & $\mathrm{SD}^{2}$ & Mean & $\mathrm{SD}$ \\
\hline 1 if (ever) Self-employed & 0.09 & 0.29 & 0.10 & 0.30 \\
1 if Intends to become self-employed & & & 0.08 & 0.27 \\
Risk attitude & 3.89 & 2.86 & 4.41 & 1.68 \\
1 if Male & 0.51 & 0.50 & 0.51 & 0.50 \\
Age & 38.82 & 10.80 & 38.77 & 11.35 \\
1 if Higher education & 0.45 & 0.50 & 0.35 & 0.48 \\
Log household income $^{3}$ & 6.35 & 0.64 & 7.56 & 0.33 \\
\hline Sample $^{3}$ & 2706 & & & 1624 & \\
\hline
\end{tabular}

${ }^{1}$ SOEP. Observations: former East Germany.

2 SD means standard deviation.

${ }^{3}$ Log household income is log of the mean of monthly household income over 2003 and 2004 in the ULMS (in Hryvna) and the the log of monthly household income (in Marks) in the SOEP in 1990.

many apartments and houses were privatized in the early years of transition, increasing heterogeneity across households with respect to access to credit since home ownership serves as a collateral to get credit at a bank. To control for this, we use household income information collected in 2003/2004 and home ownership status in 2003.

For a robustness check we use data on a sample of individuals who resided in East Germany prior to the Fall of the Berlin Wall. Akin to Ukraine, the communist regime had installed similar institutional restrictions of self-employment in East Germany that were introduced in a staggered way after 1945 and existed until $1990 .{ }^{13}$ The rules were strict and severely limited self-employment, yet they were formally less stringent than in Ukraine. ${ }^{14}$ These conditions restrained the transmission of information and the creation of business networks in the former GDR (Lechner and Pfeiffer, 1993), and hence the vast majority of East Germans had parents who could not share experiences of self-employment. The SOEP, a large representative

\footnotetext{
${ }^{13}$ Starting with agriculture in the 1950's and production firms in the 1960's, self-employment was virtually abolished. Remnants in specific sectors and occupations formally constituted self-employment in the GDR (Pickel, 1992).

${ }^{14}$ Local planning authorities had the power to decide on the entry, allocation of labour and other production factors, amount of output in terms of goods and services, and even on customer service (Prantl and Spitz-Oener 2009). Under such conditions, even though these 'enterprises' were formally private, they were not comparable to private enterprises in West Germany or in other market economies. The German Trade and Crafts Code valid in West Germany were extended to East Germany after reunification.
} 
panel survey of the adult population living in Germany covering the population of former East Germany from 1990 onwards, contains information on the intention to become self-employed that were elicited right before reunification of Germany, i.e. when self-employment became an option for East Germans for the first time. ${ }^{15}$ The exact wording of the question measuring these intentions is: 'What are your expectations for the future as far as your occupation is concerned? How probable do you consider it to be that you become self-employed in the next two years?: highly probable; probable; not very probable; highly improbable'. Based on the answer we construct an indicator variable, which takes the value one for answer categories 'highly probable' or 'probable', and the value zero for the categories 'not very probable' or 'highly improbable'. The SOEP also contains the exact same risk measure as the ULMS. ${ }^{16}$ We use household income in 1990 and home ownership (in 1990) as proxies for access to capital markets. We construct a dummy that equals one if an individual was self-employed at any time between 1991 and 2011.

\section{REsults}

We first analyse the determinants of self-employment in Ukraine, and estimate a probit model in which the dependent variable is the self-employment status. Marginal effect estimates of this probit regression evaluated at the sample means are presented in Table 2, Estimated coefficients of the probit model are shown in Table A1 in the Appendix. In column (1) of Table 2, the standardized measure of risk attitude is the only explanatory variable in the model. In the subsequent columns, sets of explanatory variables are added: demographic characteristics, size of the place of birth, proxies for household wealth, education and marital status, as well as parental background (education and occupation of father and mother), and

\footnotetext{
${ }^{15}$ For details on the SOEP data see Wagner et al. (2007).

${ }^{16}$ General willingness to take risks was first elicited in 2004 in the SOEP and measured in several subsequent waves. We take the the average of all measurements that are available for a given person, to reduce potential measurement error.
} 
regional dummies. The resulting coefficient estimate for risk attitude suggests that a two standard deviation increase in willingness to take risks is associated with a 5 to 6 percentage points higher probability of being self-employed. Compared to the sample mean of $9 \%$ (see Table 1), this is a sizable effect. It is comparable in size to the gender gap in self employment or the effect of being a home owner.

The fact that risk attitude is significantly related to self-employment even when circumstances in which direct and indirect channels through which family can affect self-employment of the children are blocked by institutional regulations suggests that the relationship between risk attitude and self-employment that has been documented in the literature (see Cramer et al. 2002 Ekelund et al., 2005; Caliendo et al., 2009, Brown et al., 2011) is unlikely to be an artifact of a third factor related to the transmission of risk attitudes and self-employment within the family or the proximate social environment. In that sense, our findings support a causal interpretation of the effect of risk preference of self-selection into self-employment, as suggested by Caliendo et al. (2009) and Brown et al. (2011). ${ }^{17}$

While previous literature has documented evidence that individuals from wealthier households have a higher likelihood of becoming self-employed (see e.g., Holtz-Eakin et al., 1994 , Lindh and Ohlsson, 1996; Blanchflower and Oswald, 1998), we do not find a significant effect of household income measured three years prior to the analysis year - arguably not a very good proxy for household wealth - on the probability of being self-employed. In line with the findings of Hurst and Lusardi (2004), members of households in the top percentiles of the wealth distribution are more likely to become self-employed. This result follows from specifications (4) and (5), which include the (log) of household income (in 1990) and a dummy variable indicating that a household is at or above the $90^{\text {th }}$ percentile of the household income distribution.

\footnotetext{
${ }^{17}$ Some regions of Ukraine, namely in the West, were annexed to the Soviet Ukraine later than the others, which might bring about some heterogeneity in the information set. Adding regional dummies (column (5)) does not, however, affect the results.
} 
TABLE 2. Self-employment in Ukraine

\begin{tabular}{|c|c|c|c|c|c|}
\hline & $(1)$ & $(2)$ & $(3)$ & $(4)$ & $(5)$ \\
\hline Risk attitude & $\begin{array}{l}0.033^{* * *} \\
(0.005)\end{array}$ & $\begin{array}{l}0.031^{* * *} \\
(0.005)\end{array}$ & $\begin{array}{l}0.028^{* * *} \\
(0.005)\end{array}$ & $\begin{array}{l}0.028^{* * *} \\
(0.005)\end{array}$ & $\begin{array}{c}0.025^{* * *} \\
(0.005)\end{array}$ \\
\hline Age & & $\begin{array}{l}0.015^{* * *} \\
(0.004)\end{array}$ & $\begin{array}{l}0.016^{* * *} \\
(0.004)\end{array}$ & $\begin{array}{l}0.014^{* * *} \\
(0.004)\end{array}$ & $\begin{array}{c}0.013^{* * *} \\
(0.004)\end{array}$ \\
\hline Age squared/100 & & $\begin{array}{c}-0.019^{* * *} \\
(0.005)\end{array}$ & $\begin{array}{c}-0.019^{* * *} \\
(0.005)\end{array}$ & $\begin{array}{c}-0.017^{* * *} \\
(0.005)\end{array}$ & $\begin{array}{c}-0.016^{* * *} \\
(0.005)\end{array}$ \\
\hline 1 if Male & & $\begin{array}{l}0.042^{* * *} \\
(0.011)\end{array}$ & $\begin{array}{l}0.043^{* * *} \\
(0.010)\end{array}$ & $\begin{array}{l}0.045^{* * *} \\
(0.011)\end{array}$ & $\begin{array}{l}0.045^{* * *} \\
(0.010)\end{array}$ \\
\hline 1 if Born in village & & & $\begin{array}{c}-0.040^{* * *} \\
(0.013)\end{array}$ & $\begin{array}{c}-0.044^{* * *} \\
(0.014)\end{array}$ & $\begin{array}{c}-0.046^{* * *} \\
(0.014)\end{array}$ \\
\hline 1 if Born in town & & & $\begin{array}{c}-0.040^{* *} \\
(0.019)\end{array}$ & $\begin{array}{c}-0.044^{* *} \\
(0.019)\end{array}$ & $\begin{array}{c}-0.051^{* * *} \\
(0.018)\end{array}$ \\
\hline 1 if Birth place unknown & & & $\begin{array}{c}-0.009 \\
(0.018)\end{array}$ & $\begin{array}{c}-0.010 \\
(0.017)\end{array}$ & $\begin{array}{c}-0.019 \\
(0.017)\end{array}$ \\
\hline 1 if Home owner ${ }^{1}$ & & & & $\begin{array}{l}0.043^{* * *} \\
(0.015)\end{array}$ & $\begin{array}{l}0.045^{* * *} \\
(0.015)\end{array}$ \\
\hline Log income in $2003 / 2004^{2}$ & & & & $\begin{array}{c}-0.025^{* *} \\
(0.011)\end{array}$ & $\begin{array}{c}-0.020^{* *} \\
(0.010)\end{array}$ \\
\hline 1 if High income ${ }^{3}$ & & & & $\begin{array}{l}0.059^{* * *} \\
(0.019)\end{array}$ & $\begin{array}{l}0.058^{* * *} \\
(0.019)\end{array}$ \\
\hline 1 if Higher education & & & & $\begin{array}{c}-0.008 \\
(0.012)\end{array}$ & $\begin{array}{c}-0.005 \\
(0.012)\end{array}$ \\
\hline 1 if Medium education & & & & $\begin{array}{c}-0.027^{* *} \\
(0.014)\end{array}$ & $\begin{array}{r}-0.024^{*} \\
(0.013)\end{array}$ \\
\hline 1 if Married & & & & $\begin{array}{r}-0.014 \\
(0.013)\end{array}$ & $\begin{array}{r}-0.015 \\
(0.012)\end{array}$ \\
\hline 1 if Has children & & & & $\begin{array}{c}0.028^{*} \\
(0.017)\end{array}$ & $\begin{array}{c}0.028^{*} \\
(0.016)\end{array}$ \\
\hline Parental background & No & No & Yes & Yes & Yes \\
\hline Regional dummies & No & No & No & No & Yes \\
\hline Sample & 2706 & 2706 & 2706 & 2706 & 2706 \\
\hline
\end{tabular}

Source: ULMS.

Note: Dependent variable is equal to 1 when individual is self-employed (zero if paid employment). Entries in the table are marginal effects after a probit estimation, evaluated at means of variables. Constant is included in all specifications. Standard errors in parentheses are clustered on household level. Stars indicate significance at $* * * \mathrm{p}<0.01,{ }^{* *} \mathrm{p}<0.05$, ${ }^{*}$ $\mathrm{p}<0.1$. Coefficient on risk attitude is standardized. Reference categories are: Lower education; Born in City. Parental background includes controls for education and occupation of mother and father.

${ }^{1} 1$ if household lives in their own property (as opposed to rented) in 2003.

${ }^{2}$ Log household income is an average of monthly household income from 2003/2004.

31 if household income in 2003/2004 was higher or equal to 90th percentile of household income distribution.

Formal education is not related to the probability of being self-employed in Ukraine, whereas being born in a village, which might reflect the lack of social connections important for setting up a business, is negatively related to self-employment. 
The regulations of the Soviet Union, which prohibited private entrepreneurship in Ukraine and promoted redistribution policies in order to equalize incomes and wealth, created a setting, in which it is unlikely that self-employment experience was transmitted from the parents. Unfortunately, we cannot pinpoint the exact timing of the decision to become self-employed in the Ukrainian sample. As our analysis of self-employment in Ukraine captures self-employment decision that were taken until 2007, it might still be that individuals acquired some information about self-employment outside the family. For example, information could have leaked from the neighbouring countries or from early-transition entrepreneurial experience, so that we cannot rule out with certainty that none of those who decided to become self-employed during this period was able to learn or gain experience about what it is like to become self-employed. In order to fully shut down the possibility of such information flows, we would need information on the intention to become self-employed at the moment that the institutional sanctions were lifted. This is why we turn to a sample of East Germans, who were asked about their intention to become self-employed exactly at the time when restrictions on self-employment were revoked.

Using data on intentions to become self-employed at the moment when self-employment legally becomes an option has at least two advantages. First, at that moment there is no opportunity to learn more about self-employment experiences from family members. Second, intentions are a snapshot of planned actions that might take time to be implemented. In other words, while the process of becoming self employed might involve several lengthy steps and hence take time, we can observe the intentions immediately. Moreover, the intention might also be less likely to be contaminated by push factors into self employment such as unemployment and might reflect what an individual prefers to do in the absence of financial constraints. Clearly in order to argue that the stated intentions are not simply cheap talk, we have to show that the expressed intention to become self-employed is also a good predictor for actually becoming self-employed. Exploiting the panel structure of the SOEP, we have also 
analysed to what extent future self-employment is predicted by the stated intentions in 1990, by regressing an indicator variable for ever having been self-employed between 1991 and 2011 on the intentions stated in 1990, controlling for risk attitudes and a full set of control variables. It turns out that the intention to become self-employed is a strong and significant predictor of the actual decision to become self-employed (see Appendix table 5).

Returning to our main question of interest, namely assessing the nature of the relation between risk attitudes and the decision to become self-employed, we estimate how risk attitudes affect the probability of expressing the intention to become self-employed among East Germans just before reunification, using data from the SOEP. We restrict the sample to individuals of German nationality who were born in East Germany. We exclude individuals who had never worked; individuals above the age of 65 ; and those who were in civil or military service in 1990. Additionally, individuals whose fathers were self-employed or self-employed farmers, as well as individuals who were self-employed themselves at the moment of the survey (less than $1 \%$ of the sample) are excluded. Table 3 presents estimated marginal effects (evaluated at the sample mean of explanatory variables) of probit models in which the dependent variable is equal to one if an individual stated that he or she is likely to become self-employed (coefficient estimates are reported in Table 5 in the Appendix). In column (1), only willingness to take risks (standardized) is included as an explanatory variable. The positive and significant effect of risk attitudes on the intention to become self-employed confirms that higher willingness to take risk is associated with a higher probability to become self-employed even in conditions of very limited knowledge about self-employment transmitted by previous generations. This result confirms that it is unlikely that the correlation between risk attitudes and self-employment is driven by parental transmission of preferences, attitudes, beliefs and information about selfemployment experience, as the self-employment was very restricted in the German Democratic Republic. 
TABLE 3. Self-employment intentions in East Germany in 1990

\begin{tabular}{|c|c|c|c|}
\hline & (1) & $(2)$ & $(3)$ \\
\hline Risk attitude & $\begin{array}{l}0.020^{* * *} \\
(0.007)\end{array}$ & $\begin{array}{l}0.019^{* * *} \\
(0.007)\end{array}$ & $\begin{array}{c}0.014^{* *} \\
(0.006)\end{array}$ \\
\hline 1 if Home owner in $1990^{1}$ & & $\begin{array}{c}0.036^{* *} \\
(0.015)\end{array}$ & $\begin{array}{c}0.033^{* *} \\
(0.014)\end{array}$ \\
\hline Log household income in 1990 & & $\begin{array}{c}0.029 \\
(0.025)\end{array}$ & $\begin{array}{c}0.009 \\
(0.024)\end{array}$ \\
\hline 1 if High household income ${ }^{2}$ & & $\begin{array}{r}-0.022 \\
(0.026)\end{array}$ & $\begin{array}{c}-0.015 \\
(0.024)\end{array}$ \\
\hline 1 if Male & & & $\begin{array}{c}0.023^{* *} \\
(0.011)\end{array}$ \\
\hline Age in 1990 & & & $\begin{array}{c}0.013^{* *} \\
(0.005)\end{array}$ \\
\hline$(\text { Age in } 1990)^{2} / 100$ & & & $\begin{array}{c}-0.018^{* * *} \\
(0.006)\end{array}$ \\
\hline 1 if Medium education & & & $\begin{array}{r}-0.001 \\
(0.033)\end{array}$ \\
\hline 1 if Higher education & & & $\begin{array}{c}0.024 \\
(0.034)\end{array}$ \\
\hline Father's occupation & No & No & Yes \\
\hline Regional dummies & No & No & Yes \\
\hline Sample & 1626 & 1626 & 1624 \\
\hline
\end{tabular}

Source: SOEP. Observations: former East Germany.

Notes: Estimation: probit. Marginal effects evaluated at sample means are reported. Dependent variable: selfemployment intention. The binary dependent variable is equal to 1 if individual intends to become self-employed (elicited in 1990). The mean of dependent variable is 0.08 . Risk attitude is the standardised average of general willingness to take risks. Clustered standard errors are in parentheses. Stars indicate significance at $* * * \mathrm{p}<0.01,{ }^{* *}$ $\mathrm{p}<0.05, * \mathrm{p}<0.1$.

11 if household lives in their own property (as opposed to rented).

21 if household income in 1990 was higher or equal to 90th percentile of household income distribution.

Controlling for access to capital markets (see column (2)) does not change the estimated effect of risk attitudes. Being a home owner, which can be used as a collateral for credit, significantly increases the stated intention to become self employed. The effect of risk attitude on the intention to become self-employed remains positive and statistically significant even after controlling for a broader set of variables (gender, age, education, father's education, regional dummies). This result confirms that the correlation between risk attitude and self-employment is not driven by parental transmission of attitudes and experiences of self employment that 
would affect children's risk preferences and their intention to become self-employed at the same time.

\section{Concluding Remarks}

The analysis of the role of risk attitude on the propensity to become self-employed under conditions in which parents cannot transmit information about own self-employment experience enhances our understanding of the nature of the relationship between willingness to take risks and entrepreneurship. Our results indicate that it is unlikely that this relationship is driven by parental background variables that simultaneously affect risk attitudes and the propensity to become self-employed. Using data on individuals from Ukraine and East Germany, whose parents could not be observed experiencing what it is like to be self-employed due to restrictive regulations on entrepreneurial activities imposed by the political regime, we provide field evidence supporting the causal interpretation of the effect of risk attitude on self-employment.

Our evidence indicates that there is a strong direct relationship between risk preferences and the self-employment decision. One potential caveat is that, although the communist regimes in Ukraine and East Germany strove to equalize financial means across households, there still existed privileges that we cannot observe in our survey data and hence cannot fully account for. In particular, some individuals might have had preferential access to knowledge and capital from the West, or might have received such information from friends or relatives living in Western countries about entrepreneurial activities. A spurious correlation might result if these privileged individuals were also more willing to take risks. However, we believe that such mechanisms are unlikely to drive the strong and significant correlation between risk attitudes and self-employment as such groups were small and because the communist governments did their best to minimize communication across borders. 
Another caveat is that there are other potential omitted factors that we have not identified in our study, but that could affect the self-employment decision. If such factors are correlated with risk attitudes, the correlation between risk attitudes and self-employment we find might suffer from omitted variable bias. One referee pointed out that the desire to work independently affects the decision to become self-employed (cf. Hundley, 2001; Benz and Frey, 2008). However, the correlation between the desire for more independence or autonomy (measure in 1990) and the willingness to take risks (measured in 2004) for our sample of East German respondents to the $\operatorname{SOEP}(N=1642)$ is virtually zero (0.0024) and insignificant (p-value 0.92$)$. In addition, previous studies have controlled for a host of other factors, and still found a positive correlation between risk attitudes and self-employment, so that we are confident that the correlation is not spurious.

Caliendo et al. (2009) also documented that the correlation is not a result of reverse causality, e.g. due to exposure to self-employment shaping risk attitudes. Yet, there remained the possibility that this correlation was driven by a third factor. The most plausible channel is arguably the simultaneous transmission of risk attitudes and information about what it is like to be self-employed from parents to children. We have exploited a historical setting in which this channel is practically shut down, and shown that the strong significant correlation between risk attitudes and self-employment remains intact in our setting. Our results hence support a causal interpretation of the relation between risk preferences and the decision to become self-employed. 


\section{REFERENCES}

Andersson, L. and Hammarstedt, M. (2010). Intergenerational transmissions in immigrant selfemployment: Evidence from three generations. Small Business Economics, 34(3):261-276.

Andruhin, E. (2011). Entrepreneurship in the Soviet Union during 1950-1980's. PhD thesis, Kursk State University.

Benz, M. and Frey, B. S. (2008). Being independent is a great thing: Subjective evaluations of self-employment and hierarchy. Economica, 75(298):362-383.

Blanchflower, D. G. and Oswald, A. J. (1998). What Makes an Entrepreneur? Journal of Labor Economics, 16(1):26-60.

Brown, S., Dietrich, M., Ortiz-Nuñez, A., and Taylor, K. (2011). Self-employment and attitudes towards risk: Timing and unobserved heterogeneity. Journal of Economic Psychology, $32(3): 425-433$.

Burke, A. E., FitzRoy, F. R., and Nolan, M. A. (2002). Self-employment Wealth and Job Creation: The Roles of Gender, Non-pecuniary Motivation and Entrepreneurial Ability. Small Business Economics, 19:255-270.

Caliendo, M., Fossen, F. M., and Kritikos, A. S. (2009). Risk attitudes of nascent entrepreneurs: new evidence from an experimentally validated survey. Small Business Economics, 32(2):153167.

Cramer, J., Hartog, J., Jonker, N., and van Praag, C. M. (2002). Low Risk Aversion Encourages the Choice for Entrepreneurship: An Empirical Test of a Truism. Journal of Economic Behavior \& Organization, 48:29-36.

Dohmen, T., Falk, A., Huffman, D., and Sunde, U. (2012). The Intergenerational Transmission of Risk and Trust Attitudes. The Review of Economic Studies, 79(2):645-677.

Dohmen, T., Falk, A., Huffman, D., Sunde, U., Schupp, J., and Wagner, G. G. (2011). Individual Risk Attitudes: Measurement, Determinants, and Behavioral Consequences. Journal of the European Economic Association, 9(3):522-550.

Dunn, T. and Holtz-Eakin, D. (2000). Financial Capital, Human Capital, and the Transition to Self-Employment: Evidence from Intergenerational Links. Journal of Labor Economics, 18(2):282-305.

Ekelund, J., Johansson, E., Jarvelin, M., and Lichtermann, D. (2005). Self-employment and risk aversion: evidence from psychological test data. Labour Economics, 12(5):649-659. 
Evans, D. S. and Jovanovic, B. (1989). An Estimated Model of Entrepreneurial Choice under Liquidity Constraints. Journal of Political Economy, 97(4):808-827.

Evans, D. S. and Leighton, L. S. (1989). Some Empirical Aspects of Entrepreneurship. The American Economic Review, 79(3):519-535.

Fairlie, R. W. and Robb, A. (2007). Families, Human Capital, and Small Business: Evidence from the Characteristics of Business Owners Survey. Industrial and Labor Relations Review, $60(2): 225-245$.

Falter, J.-M. (2007a). Entrepreneurship and Intergenerational Links in Switzerland. Labour, 21(1):121-134.

Falter, J.-M. (2007b). Self-employment and earning inequality. Journal of Income Distribution, 16(2):106-127.

Fossen, F. M. (2011). The Private Equity Premium Puzzle Revisited-New Evidence on the Role of Heterogeneous Risk Attitudes. Economica, 78(312):656-675.

Gelfand, I. (1964). Criminal responsibility for (trade) speculation. Kiev.

Gomez, R. and Santor, E. (2001). Membership has its privileges: the effect of social capital and neighbourhood characteristics on the earnings of microfinance borrowers. The Canadian Journal of Economics, 34(4):943-966.

Hartog, J. and van Praag, C. M. (2010). If you are so smart, why aren't you an entrepreneur? Returns to cognitive and social ability: Entrepreneurs versus employees. Journal of Economics and Management Strategy, 19(4):947-989.

Holtz-Eakin, D., Joulfaian, D., and Rosen, H. S. (1994). Sticking It Out: Entrepreneurial Survival and Liquidity Constraints. The Journal of Political Economy, 102(1):53-75.

Hout, M. and Rosen, H. (2000). Self-Employment, Family Background, and Race. Journal of Human Resources, 35(4):670-692.

Hundley, G. (2001). Why and when are the self-employed more satisfied with their work? Industrial Relations: A Journal of Economy and Society, 40(2):293-316.

Hundley, G. (2006). Family Background and the Propensity for Self-Employment. Industrial Relations, 45(3):377-392.

Hurst, E. and Lusardi, A. (2004). Liquidity Constraints, Household Wealth, and Entrepreneurship. Journal of Political Economy, 112(2):319-347.

Kihlstrom, R. E. and Laffont, J.-J. (1979). A General Equilibrium Entrepreneurial Theory of Firm Formation Based on Risk Aversion. Journal of Political Economy, 87(4):719-748.

Knight, F. H. (1921). Risk, Uncertainty and Profit. Houghton-Mifflin, New York. 
Lazear, E. P. (2004). Balanced Skills and Entrepreneurship. The American Economic Review, 94(2):208-211.

Lazear, E. P. (2005). Entrepreneurship. Journal of Labour Economics, 23(4):649-680.

Lechner, M. and Pfeiffer, F. (1993). Planning for self-employment at the beginning of a market economy: Evidence from individual data of East German workers. Small Business Economics, $5(2): 111-128$.

Lehmann, H., Muravyev, A., and Zimmermann, K. (2012). The Ukrainian Longitudinal Monitoring Survey: Towards a Better Understanding of Labor Markets in Transition. IZA Journal of Labor \& Development, 1(1):9.

Lindh, T. and Ohlsson, H. (1996). Self-employment and windfall gains: Evidence from the Swedish lottery. The Economic Journal, 106(439):pp. 1515-1526.

Parker, S. C. (1999). The inequality of employment and self-employment incomes: a decomposition analysis for the U.K. Review of Income and Wealth, 45(2):263-274.

Pickel, A. (1992). Radical transitions: the survival and revival of entrepreneurship in the GDR. Westview press, HarperCollins Canada.

Praag, C. v. and Ophem, H. V. (1995). Determinants of willingness and opportunity to start as an entrepreneur. Kyklos, 48(4):513-540.

Prantl, S. and Spitz-Oener, A. (2009). How does entry regulation influence entry into selfemployment and occupational mobility? Economics of Transition, 17(4):769-802.

Rees, H. and Shah, A. (1986). An empirical analysis of self-employment in the U.K. Journal of Applied Econometrics, 1(1):95-108.

Rosen, H. and Willen, P. (2002). Risk, return and self-employment. University of Chicago/Princeton University Discussion Paper.

Schiller, B. R. and Crewson, P. E. (1997). Entrepreneurial Origins: a Longitudinal Inquiry. Economic Inquiry, 35(3):523-531.

Schumpeter, J. A. (1934). The Theory of Economic Development. Harvard University Press, Cambridge, MA.

Schumpeter, J. A. (1939). Business Cycles. McGraw-Hill, New York.

Trofimov, S. (1975). Struggle against the forbidden trade in Ukrainian SSR. RIO by MOOP USSR, Kiev.

van Praag, C. M. and Cramer, J. (2001). The Roots of Entrepreneurship and Labour Demand: Individual Ability and Low Risk Aversion. Economica, 68(269):45-62.

Wagner, G. G., Frick, J. R., and Schupp, J. (2007). The German Socio-Economic Panel Study (SOEP) - Scope, Evolution and Enhancements. DIW Berlin. 


\section{Appendix tables}

TABLE 4. Self-employment in Ukraine: all coefficients

\begin{tabular}{|c|c|c|c|c|c|}
\hline & (1) & $(2)$ & (3) & (4) & $(5)$ \\
\hline Risk attitude & $\begin{array}{l}0.211^{* * *} \\
(0.035)\end{array}$ & $\begin{array}{l}0.202^{* * *} \\
(0.037)\end{array}$ & $\begin{array}{l}0.191^{* * *} \\
(0.037)\end{array}$ & $\begin{array}{l}0.196^{* * *} \\
(0.037)\end{array}$ & $\begin{array}{l}0.186^{* * *} \\
(0.039)\end{array}$ \\
\hline Age & & $\begin{array}{l}0.102^{\text {*** }} \\
(0.025)\end{array}$ & $\begin{array}{l}0.107^{* * *} \\
(0.026)\end{array}$ & $\begin{array}{l}0.098^{* * *} \\
(0.028)\end{array}$ & $\begin{array}{l}0.097^{* * *} \\
(0.029)\end{array}$ \\
\hline Age squared/100 & & $\begin{array}{c}-0.126^{* * *} \\
(0.033)\end{array}$ & $\begin{array}{c}-0.129^{* * *} \\
(0.034)\end{array}$ & $\begin{array}{c}-0.120^{* * *} \\
(0.036)\end{array}$ & $\begin{array}{c}-0.119^{* * *} \\
(0.036)\end{array}$ \\
\hline 1 if Male & & $\begin{array}{l}0.277^{* * *} \\
(0.069)\end{array}$ & $\begin{array}{l}0.297^{* * *} \\
(0.071)\end{array}$ & $\begin{array}{l}0.322^{* * *} \\
(0.077)\end{array}$ & $\begin{array}{l}0.339^{* * *} \\
(0.078)\end{array}$ \\
\hline 1 if Born in village & & & $\begin{array}{c}-0.275^{* * *} \\
(0.093)\end{array}$ & $\begin{array}{c}-0.310^{* * *} \\
(0.098)\end{array}$ & $\begin{array}{c}-0.346^{* * *} \\
(0.104)\end{array}$ \\
\hline 1 if Born in town & & & $\begin{array}{c}-0.276^{* *} \\
(0.133)\end{array}$ & $\begin{array}{c}-0.311^{* *} \\
(0.134)\end{array}$ & $\begin{array}{c}-0.384^{* * *} \\
(0.136)\end{array}$ \\
\hline 1 if Born in unknown settlement & & & $\begin{array}{c}-0.063 \\
(0.122)\end{array}$ & $\begin{array}{c}-0.071 \\
(0.124)\end{array}$ & $\begin{array}{c}-0.141 \\
(0.126)\end{array}$ \\
\hline 1 if Home owner & & & & $\begin{array}{l}0.303^{* * *} \\
(0.109)\end{array}$ & $\begin{array}{l}0.338^{* * *} \\
(0.114)\end{array}$ \\
\hline Log household income in $2003 / 2004$ & & & & $\begin{array}{c}-0.179^{* *} \\
(0.077)\end{array}$ & $\begin{array}{c}-0.151 * * \\
(0.076)\end{array}$ \\
\hline 1 if High household income & & & & $\begin{array}{l}0.420^{* * *} \\
(0.138)\end{array}$ & $\begin{array}{c}0.439^{* * *} \\
(0.141)\end{array}$ \\
\hline 1 if Higher education & & & & $\begin{array}{c}-0.059 \\
(0.089)\end{array}$ & $\begin{array}{c}-0.037 \\
(0.090)\end{array}$ \\
\hline 1 if Medium education & & & & $\begin{array}{c}-0.195^{* *} \\
(0.099)\end{array}$ & $\begin{array}{r}-0.184^{*} \\
(0.101)\end{array}$ \\
\hline 1 if Married & & & & $\begin{array}{r}-0.102 \\
(0.091)\end{array}$ & $\begin{array}{r}-0.113 \\
(0.092)\end{array}$ \\
\hline 1 if Has children & & & & $\begin{array}{c}0.196^{*} \\
(0.118)\end{array}$ & $\begin{array}{c}0.208^{*} \\
(0.119)\end{array}$ \\
\hline 1 if Mother has medium education & & & $\begin{array}{c}0.083 \\
(0.114)\end{array}$ & $\begin{array}{c}0.097 \\
(0.115)\end{array}$ & $\begin{array}{c}0.102 \\
(0.119)\end{array}$ \\
\hline 1 if Mother has higher education & & & $\begin{array}{c}0.124 \\
(0.187)\end{array}$ & $\begin{array}{c}0.145 \\
(0.194)\end{array}$ & $\begin{array}{c}0.123 \\
(0.197)\end{array}$ \\
\hline 1 if Mother's education unknown & & & $\begin{array}{c}-0.333 \\
(0.248)\end{array}$ & $\begin{array}{c}-0.354 \\
(0.249)\end{array}$ & $\begin{array}{r}-0.373 \\
(0.247)\end{array}$ \\
\hline 1 if Father has medium education & & & $\begin{array}{c}0.096 \\
(0.116)\end{array}$ & $\begin{array}{c}0.101 \\
(0.118)\end{array}$ & $\begin{array}{c}0.076 \\
(0.119)\end{array}$ \\
\hline 1 if Father has higher education & & & $\begin{array}{c}0.077 \\
(0.176)\end{array}$ & $\begin{array}{c}0.115 \\
(0.174)\end{array}$ & $\begin{array}{c}0.099 \\
(0.175)\end{array}$ \\
\hline 1 if Father's education unknown & & & $\begin{array}{c}0.070 \\
(0.169)\end{array}$ & $\begin{array}{c}0.076 \\
(0.168)\end{array}$ & $\begin{array}{c}0.014 \\
(0.168)\end{array}$ \\
\hline 1 if Mother legislator & & & $\begin{array}{r}-0.016 \\
(0.323)\end{array}$ & $\begin{array}{r}-0.028 \\
(0.328)\end{array}$ & $\begin{array}{r}-0.011 \\
(0.329)\end{array}$ \\
\hline 1 if Mother professional & & & $\begin{array}{c}-0.265 \\
(0.194)\end{array}$ & $\begin{array}{c}-0.293 \\
(0.203)\end{array}$ & $\begin{array}{c}-0.289 \\
(0.208)\end{array}$ \\
\hline
\end{tabular}

Note: Table is continued on the next page. 
(Table 5 continued).

1 if Mother associate professional

1 if Mother technician

1 if Mother service worker

1 if Mother agricultural worker

1 if Mother craft worker

1 if Mother machine operator

1 if Mother's occupation missing

1 if Father legislator

1 if Father professional

1 if Father associate professional

1 if Father technician

1 if Father service worker

1 if Father agricultural worker

1 if Father craft worker

1 if Father machine operator

1 if Father's occupation missing

1 if Father military occupation

(1)

(3)

(4)

(5)

$\begin{array}{lll}-0.032 & -0.053 & -0.062\end{array}$

$\begin{array}{lll}(0.134) & (0.135) & (0.138)\end{array}$

$\begin{array}{lll}0.063 & 0.062 & 0.086\end{array}$

$\begin{array}{lll}(0.152) & (0.155) & (0.162)\end{array}$

$\begin{array}{lll}0.131 & 0.132 & 0.128\end{array}$

$\begin{array}{lll}(0.136) & (0.135) & (0.137)\end{array}$

$\begin{array}{lll}-0.008 & 0.013 & 0.031\end{array}$

$\begin{array}{lll}(0.256) & (0.255) & (0.256)\end{array}$

$\begin{array}{lll}-0.259^{*} & -0.236^{*} & -0.209\end{array}$

$\begin{array}{lll}(0.140) & (0.141) & (0.142)\end{array}$

$\begin{array}{lll}-0.123 & -0.053 & -0.075\end{array}$

$\begin{array}{lll}(0.314) & (0.312) & (0.325)\end{array}$

$\begin{array}{lll}-0.019 & 0.003 & 0.027\end{array}$

$\begin{array}{lll}(0.115) & (0.118) & (0.122)\end{array}$

$\begin{array}{lll}0.333^{*} & 0.267 & 0.129\end{array}$

$\begin{array}{lll}(0.193) & (0.193) \quad(0.201)\end{array}$

$\begin{array}{lll}-0.088 & -0.096 & -0.117\end{array}$

$\begin{array}{lll}(0.213) & (0.214) \quad(0.212)\end{array}$

$\begin{array}{lll}-0.225 & -0.217 & -0.240\end{array}$

$\begin{array}{lll}(0.195) & (0.199) \quad(0.203)\end{array}$

$\begin{array}{lll}0.118 & 0.103 & 0.056\end{array}$

$\begin{array}{lll}(0.267) & (0.273) \quad(0.269)\end{array}$

$\begin{array}{lll}-0.046 & -0.095 & -0.137\end{array}$

$\begin{array}{lll}(0.411) & (0.413) \quad(0.399)\end{array}$

$\begin{array}{lll}0.045 & 0.039 & 0.006\end{array}$

$\begin{array}{lll}(0.227) & (0.227) \quad(0.226)\end{array}$

$\begin{array}{lll}-0.091 & -0.064 & -0.059\end{array}$

$\begin{array}{lll}(0.124) & (0.125) \quad(0.128)\end{array}$

$\begin{array}{lll}-0.026 & -0.041 & -0.074\end{array}$

$\begin{array}{lll}(0.137) & (0.139) \quad(0.140)\end{array}$

$\begin{array}{lll}0.089 & 0.054 & 0.003\end{array}$

$\begin{array}{lll}(0.246) & (0.242) \quad(0.251)\end{array}$

$\begin{array}{lll}-0.028 & -0.030 & -0.024\end{array}$

$\begin{array}{lll}(0.146) & (0.146) \quad(0.147)\end{array}$

Constant

$-1.368^{* * *}-3.435^{* * *}$

$-3.493^{* * *}$

$-2.467^{* * *} \quad-2.799^{* * *}$

$$
\text { (0.038) }
$$

(0.507)

(0.707)

(0.705)

\begin{tabular}{lccccc} 
Regional dummies & No & No & No & No & Yes \\
\hline Sample & 2726 & 2726 & 2726 & 2726 & 2726 \\
\hline
\end{tabular}

Source: ULMS.

Note: Estimation: probit. Coefficients are reported. Dependent variable is equal to 1 when individual is self-employed (zero if paid employment). The mean of dependent variable is 0.09 . Coefficient on risk attitude is standardized. Clustered standard errors are in parentheses. Stars indicate significance at ${ }^{* * *} \mathrm{p}<0.01,{ }^{* *} \mathrm{p}<0.05,{ }^{*} \mathrm{p}<0.1$. In column

(5) 25 regional dummies are included. 
TABLE 5. Self-employment and self-employment intentions in East Germany

\begin{tabular}{|c|c|c|c|}
\hline & (1) & $(2)$ & (3) \\
\hline 1 if Self-employment intention & $\begin{array}{l}1.172^{* * *} \\
(0.123)\end{array}$ & $\begin{array}{l}1.130^{* * *} \\
(0.124)\end{array}$ & $\begin{array}{l}1.105^{* * *} \\
(0.126)\end{array}$ \\
\hline Risk attitude & & $\begin{array}{l}0.269^{* * *} \\
(0.047)\end{array}$ & $\begin{array}{l}0.221^{* * *} \\
(0.050)\end{array}$ \\
\hline 1 if Home owner in $1990^{2}$ & & $\begin{array}{c}0.033 \\
(0.102)\end{array}$ & $\begin{array}{c}0.118 \\
(0.108)\end{array}$ \\
\hline Log household income in 1990 & & $\begin{array}{l}0.625^{* * *} \\
(0.177)\end{array}$ & $\begin{array}{l}0.576^{* * *} \\
(0.195)\end{array}$ \\
\hline 1 if High household income ${ }^{2}$ & & $\begin{array}{c}-0.179 \\
(0.182)\end{array}$ & $\begin{array}{c}-0.136 \\
(0.191)\end{array}$ \\
\hline 1 if Male & & & $\begin{array}{c}0.192^{* *} \\
(0.095)\end{array}$ \\
\hline Age in 1990 & & & $\begin{array}{c}0.042 \\
(0.038)\end{array}$ \\
\hline$(\text { Age in } 1990)^{2} / 100$ & & & $\begin{array}{c}-0.100^{* *} \\
(0.049)\end{array}$ \\
\hline 1 if Medium education & & & $\begin{array}{c}0.330 \\
(0.276)\end{array}$ \\
\hline 1 if Higher education & & & $\begin{array}{c}0.652^{* *} \\
(0.281)\end{array}$ \\
\hline 1 if Brandenburg & & & $\begin{array}{c}-0.088 \\
(0.241)\end{array}$ \\
\hline 1 if Mecklenburg-Western Pomerania & & & $\begin{array}{r}-0.187 \\
(0.251)\end{array}$ \\
\hline 1 if Saxony & & & $\begin{array}{c}-0.064 \\
(0.220)\end{array}$ \\
\hline 1 if Brandenburg & & & $\begin{array}{c}-0.204 \\
(0.240)\end{array}$ \\
\hline 1 if Thuringia & & & $\begin{array}{c}-0.060 \\
(0.234)\end{array}$ \\
\hline 1 if Father unemployed, pensioner, or no answer & & & $\begin{array}{c}0.012 \\
(0.248)\end{array}$ \\
\hline 1 if Father untrained & & & $\begin{array}{c}-0.041 \\
(0.320)\end{array}$ \\
\hline 1 if Father semi-trained or blue-collar worker & & & $\begin{array}{c}-0.040 \\
(0.241)\end{array}$ \\
\hline 1 if Father foreman or team leader & & & $\begin{array}{c}0.285 \\
(0.258)\end{array}$ \\
\hline 1 if Father civil servant & & & $\begin{array}{c}0.327 \\
(0.495)\end{array}$ \\
\hline 1 if Father managerial or high qualified & & & $\begin{array}{c}0.339 \\
(0.237)\end{array}$ \\
\hline 1 if Father agricultural worker & & & $\begin{array}{c}-0.076 \\
(0.259)\end{array}$ \\
\hline Constant & $\begin{array}{c}-1.442^{* * *} \\
(0.050)\end{array}$ & $\begin{array}{c}-6.224^{* * *} \\
(1.338)\end{array}$ & $\begin{array}{c}-6.544^{* * *} \\
(1.657)\end{array}$ \\
\hline Sample & 1626 & 1626 & 1624 \\
\hline
\end{tabular}

Source: SOEP. Observations: former East Germany.

Notes: Estimation: probit. Coefficients are reported. Dependent variable: self-employment between 1991 and 2011.

Clustered standard errors are in parentheses. Stars indicate significance at ${ }^{* * *} \mathrm{p}<0.01,{ }^{* *} \mathrm{p}<0.05,{ }^{*} \mathrm{p}<0.1$.

${ }^{1} 1$ if household resides in own property (as opposed to rented).

21 if household income in 1990 was higher or equal to 90th percentile of household income distribution. 
TABLE 6. Self-employment intentions in 1990

\begin{tabular}{|c|c|c|c|}
\hline & $(1)$ & $(2)$ & $(3)$ \\
\hline Risk attitude & $\begin{array}{l}0.137^{* * *} \\
(0.047)\end{array}$ & $\begin{array}{l}0.138^{* * *} \\
(0.048)\end{array}$ & $\begin{array}{c}0.107^{* *} \\
(0.050)\end{array}$ \\
\hline 1 if Home owner in $1990^{1}$ & & $\begin{array}{c}0.253^{* *} \\
(0.107)\end{array}$ & $\begin{array}{c}0.260^{* *} \\
(0.113)\end{array}$ \\
\hline Log household income in 1990 & & $\begin{array}{c}0.203 \\
(0.180)\end{array}$ & $\begin{array}{c}0.067 \\
(0.191)\end{array}$ \\
\hline 1 if High household income ${ }^{2}$ & & $\begin{array}{r}-0.158 \\
(0.181)\end{array}$ & $\begin{array}{r}-0.120 \\
(0.190)\end{array}$ \\
\hline 1 if Male & & & $\begin{array}{c}0.179^{* *} \\
(0.087)\end{array}$ \\
\hline Age in 1990 & & & $\begin{array}{c}0.097^{* *} \\
(0.038)\end{array}$ \\
\hline$(\text { Age in } 1990)^{2} / 100$ & & & $\begin{array}{c}-0.143^{* * *} \\
(0.048)\end{array}$ \\
\hline 1 if Medium education & & & $\begin{array}{c}-0.005 \\
(0.254)\end{array}$ \\
\hline 1 if Higher education & & & $\begin{array}{c}0.185 \\
(0.263)\end{array}$ \\
\hline 1 if Brandenburg & & & $\begin{array}{r}-0.128 \\
(0.252)\end{array}$ \\
\hline 1 if Mecklenburg-Western Pomerania & & & $\begin{array}{c}0.124 \\
(0.254)\end{array}$ \\
\hline 1 if Saxony & & & $\begin{array}{r}-0.060 \\
(0.227)\end{array}$ \\
\hline 1 if Brandenburg & & & $\begin{array}{r}-0.067 \\
(0.239)\end{array}$ \\
\hline 1 if Thuringia & & & $\begin{array}{c}0.028 \\
(0.241)\end{array}$ \\
\hline 1 if Father unemployed, pensioner, or no answer & & & $\begin{array}{r}-0.043 \\
(0.208)\end{array}$ \\
\hline 1 if Father untrained & & & $\begin{array}{c}0.147 \\
(0.272)\end{array}$ \\
\hline 1 if Father semi-trained or blue-collar worker & & & $\begin{array}{r}-0.094 \\
(0.207)\end{array}$ \\
\hline 1 if Father foreman or team leader & & & $\begin{array}{c}0.151 \\
(0.248)\end{array}$ \\
\hline 1 if Father civil servant & & & $\begin{array}{c}1.067^{* *} \\
(0.424)\end{array}$ \\
\hline 1 if Father managerial or high qualified & & & $\begin{array}{r}-0.157 \\
(0.216)\end{array}$ \\
\hline 1 if Father agricultural worker & & & $\begin{array}{c}-0.148 \\
(0.224)\end{array}$ \\
\hline Constant & $\begin{array}{c}-1.431^{* * *} \\
(0.051)\end{array}$ & $\begin{array}{c}-3.036^{* *} \\
(1.350)\end{array}$ & $\begin{array}{c}-3.572^{* *} \\
(1.515)\end{array}$ \\
\hline Sample & 1626 & 1626 & 1624 \\
\hline
\end{tabular}

Source: SOEP. Observations: former East Germany.

Notes: Estimation: probit. Coefficients are reported. Dependent variable: self-employment intention. Clustered standard errors are in parentheses. Stars indicate significance at ${ }^{* * *} \mathrm{p}<0.01,{ }^{* *} \mathrm{p}<0.05,{ }^{*} \mathrm{p}<0.1$.

${ }^{1} 1$ if household lives in their own property (as opposed to rented).

21 if household income in 1990 was higher or equal to 90th percentile of household income distribution. 